\title{
Anatomical Features of the Tubercle and Young Sporophyte of the Annual Fern Anogramma chaerophylla Growing in the Punta Lara Natural Reserve (Buenos Aires, Argentina)
}

Author(s): María Luján Luna Juan Pablo Ramos Giacosa Agustina Yáñez Gabriela Elena Giudice

Source: American Fern Journal, 106(4):231-241.

Published By: The American Fern Society

DOI: http://dx.doi.org/10.1640/0002-8444-106.4.231

URL: http://www.bioone.org/doi/full/10.1640/0002-8444-106.4.231

BioOne (www.bioone.org) is a nonprofit, online aggregation of core research in the biological, ecological, and environmental sciences. BioOne provides a sustainable online platform for over 170 journals and books published by nonprofit societies, associations, museums, institutions, and presses.

Your use of this PDF, the BioOne Web site, and all posted and associated content indicates your acceptance of BioOne's Terms of Use, available at www.bioone.org/ page/terms_of_use.

Usage of BioOne content is strictly limited to personal, educational, and noncommercial use. Commercial inquiries or rights and permissions requests should be directed to the individual publisher as copyright holder. 


\title{
Anatomical Features of the Tubercle and Young Sporophyte of the Annual Fern Anogramma chaerophylla Growing in the Punta Lara Natural Reserve (Buenos Aires, Argentina)
}

\author{
MARÍA LuJÁN LUNA* \\ Cátedra Morfología Vegetal, Facultad de Ciencias Naturales y Museo (UNLP), Boulevard 120 y 61, \\ C.P.1900, La Plata, Argentina. Comisión de Investigaciones Científicas de la Provincia de Buenos \\ Aires (CIC-BA), Argentina, lujanluna@fcnym.unlp.edu.ar \\ Juan Pablo Ramos Giacosa \\ Cátedra Morfología Vegetal, Facultad de Ciencias Naturales y Museo (UNLP). Boulevard 120 y 61, \\ C.P.1900, La Plata, Argentina. Consejo Nacional de Investigaciones Científicas y Tecnológicas \\ (CONICET), Argentina, jpramosgiacosa@hotmail.com

\section{Agustina YÁÑEZ} \\ Cátedra Morfología Vegetal, Facultad de Ciencias Naturales y Museo (UNLP), Boulevard 120 y 61, \\ C.P.1900, La Plata, Argentina. Museo Argentino de Ciencias Naturales Bernardino Rivadavia, Av. \\ Ángel Gallardo 470, C1405DJR, Ciudad Autónoma de Buenos Aires, Argentina. Consejo Nacional \\ de Investigaciones Científicas y Tecnológicas (CONICET), Argentina, yanez_agustina@hotmail.com

\section{Gabriela Elena Giudice} \\ Cátedra Morfología Vegetal, Facultad de Ciencias Naturales y Museo (UNLP), Boulevard 120 y 61, \\ C.P.1900, La Plata, Argentina, gegiudice@hotmail.com
}

\begin{abstract}
Aвstract.-The fern genus Anogramma is characterized by the presence of annual sporophytes and tubercles that persist through dry periods. Tubercles may host embryos that develop when climatic conditions are more favorable. As information on the structure of the tubercle and sporophyte of Anogramma chaerophylla is incomplete, the objective of this work was to analyze anatomical characteristics during development and deepen knowledge of the adaptive strategies of this species. Spores were grown in-vitro and different stages of tubercle development and embryonic sporophytes were fixed in FAA, embedded in Paraplast and analyzed using light microscopy. Initially, the green gametophyte developed antheridia and archegonia in its thickened portion, where later bisexual tubercles differentiated. Embryos developed only from the archegonia located in the tubercles, with one embryo developing per tubercule. During sporophyte growth the reserves accumulated in the tubercle were consumed. Oversized cells were observed at the junction between the green gametophyte and the tubercle, suggesting a possible role in translocation of substances. The young sporophyte consisted of a short shoot and a prominent foot. The placenta comprised the foot cells and the adjacent tubercle cells. The first leaves protruded soon and developed early as photosynthetic organs. Sporophytes remained attached to the tubercles until advanced stages of development. Vegetative propagation was documented in smaller tubercles that did not develop gametangia. Because few sporophytes were observed in vivo, it is likely that natural populations are maintained through vegetative propagation of the gametophyte until favorable conditions encourage development of sporophytes.
\end{abstract}

KEY WorDs.-anatomy, gametophyte, embryo, adaptations, Anogramma

\footnotetext{
* Corresponding author
} 
Anogramma Link (Pteridaceae) is a homosporous fern genus with seven species distributed mainly in the tropics of Mexico and Central and South America and less frequently in Africa, from southern Europe to northern India, and in Australia and New Zealand (Tryon et al., 1990; Nakazato and Gastony, 2003). In Argentina, Anogramma is represented by two species: Anogramma chaerophylla (Desv.) Link and Anogramma lorentzii (Hieron.) Diels.

The genus is characterized by the presence of annual sporophytes $\left(1 \_40 \mathrm{~cm}\right.$ height) that often grow in environments with alternating wet and dry seasons. A striking feature of Anogramma is that gametophytes are considered perennial because they carry tubercles that can become dormant during stressful periods, or support the expansion of a latent embryo when favorable conditions arrive (Goebel, 1889; Baroutsis, 1976; Mehra and Sandhu, 1976; Page, 2002). Bower (1923) described the tubercles as "archegoniophores" because they carry numerous archegonia.

Most studies on gametophyte development and morphology were conducted in the widely distributed species Anogramma leptophylla (L.) Link (Mehra and Sandu, 1976; Pangua and Vega, 1996; Hagemann, 1997). Goebel (1889) described the first stages of gametophyte development for Anogramma chaerophylla and mentioned that the tubercles store starch grains and other food reserves. Later, Hagemann (1997) extended study of the gametophyte of A. chaerophylla by describing meticulously its development and tubercle formation.

Anogramma chaerophylla is widely distributed in Central and South America, from Mexico, El Salvador and the Greater Antilles to the Galapagos, Brazil, Paraguay, Uruguay, and Argentina (Mickel and Smith, 2004). In Argentina, this species grows from Misiones and Jujuy Provinces in the north, through the center-east of the country, reaching its southernmost distribution in Buenos Aires Province (Zuloaga, Morrone, and Belgrano, 2008).

Because information on tubercle and sporophyte structure and development in Anogramma chaerophylla is incomplete, the objective of this work was to analyze the anatomical characteristics of both stages at different times during their formation. This knowledge may contribute to understanding adaptive strategies in ferns.

\section{Materials AND Methods}

Sampling area.-Fertile fronds were collected in Punta Lara Natural Reserve, Buenos Aires, Argentina ( $34^{\circ} 47^{\prime} \mathrm{S}, 58^{\circ} 01^{\prime} \mathrm{W}$ ) spanning three years (2012-2014) from November to April. The Reserve is situated on the Coast of La Plata River where the mean annual temperature is $16.5^{\circ} \mathrm{C}$ and the precipitation averages $950 \mathrm{~mm}$ per year, with fluctuating periods of flooding and drought. In this habitat, ferns grow mainly associated with the gallery forests that border the internal streams. During hikes in the Reserve in different seasons few plants of Anogramma chaerophylla growing in isolation were observed.

Cultivation of spores.-To analyze different stages of tubercle and sporophyte development, spores were grown in vitro. Portions of fronds 
with mature closed sporangia were placed in paper envelopes until spore release. Then, spores were sown in previously sterilized Petri dishes, $5 \mathrm{~cm}$ in diameter containing Murashige-Skoog medium (Murashige and Skoog, 1962) and Difco Bacto-agar (7 g/l). Twenty dishes were prepared and kept under laboratory conditions, with a photoperiod of 12 hours light under white fluorescent illumination $28 \mu \mathrm{mol} \mathrm{m}^{-2} \mathrm{~s}^{-1}$ at $22-24^{\circ} \mathrm{C}$.

Cultivation of gametophytes and sporophytes.-Once gametophytes acquired their typical helical shape, they were transferred to plastic pots with fertile soil and brought outdoors covered by a black shadow cloth. The pots were watered weekly. Different phases of gametophyte and sporophyte development were detected through weekly observations under a stereoscopic microscope (Nikon SMZ 1000).

Anatomical study.-The structure of the gametophyte, tubercle, and sporophyte at different developmental stages was analyzed under a light microscope. Materials were fixed in formaldehyde-acetic acid-alcohol, dehydrated through an ethanol series and embedded in Paraplast. Microtome sections (8-10 $\mu \mathrm{m}$ thick) were double stained with safranin-fast green (Johansen, 1940). Polarized light and Lugol's solution were used to ascertain the presence of starch grains (D’Ambroggio de Argüeso, 1986). Observations and photographs were carried out with a Nikon E200 light microscope.

\section{RESUlTS}

Green thalloid gametophyte.-The initial filament emerging from the spore divides longitudinally, producing a spatula-shaped structure with a lateral meristem. The spore germination pattern corresponds to the Vittaria type and the prothallus development is Ceratopteris type (Luna et al., in press). The gametophyte continues to develop asymmetrically, bending itself around the growth zone to acquire a funnel shape (Fig. 1A). The innermost zone has multiple cell layers, which then decrease to only a single-cell layer in thickness along the exterior of the gametophyte (Fig. 1B). Archegonia and antheridia are differentiated in the thickened portion of the gametophyte, together with numerous rhizoids. The neck of the archegonium protrudes from the gametophyte and its diameter is made up by 4 rows of cells and is $4 \_5$ cells in length (Fig. 1C). The antheridium consists of the basal cell, the ring cell, and the cap cell (Fig 1D). Gametangia continue differentiating a certain distance from the multicellular portion. In some instances, fertilization is evidenced by the presence of a zygote and then an embryo (Figs. 1E-G). At this point of gametophyte development tubercles have already originated.

Gametophyte tubercle.-The origin of tubercles is revealed by the appearance of rounded, whitish (non-photosynthetic) structures in the gametophyte meristematic region (Fig. 2A). The surface of the tubercle is covered by abundant rhizoids (Fig. 2B). At this stage of tubercle development, both the green gametophyte and the tubercle contain gametangia (Fig. 2C). Tubercles are bisexual, i.e., archegonia as well as antheridia are developed, the former in increased number (Figs. 2D-F). The venters of the archegonia are 

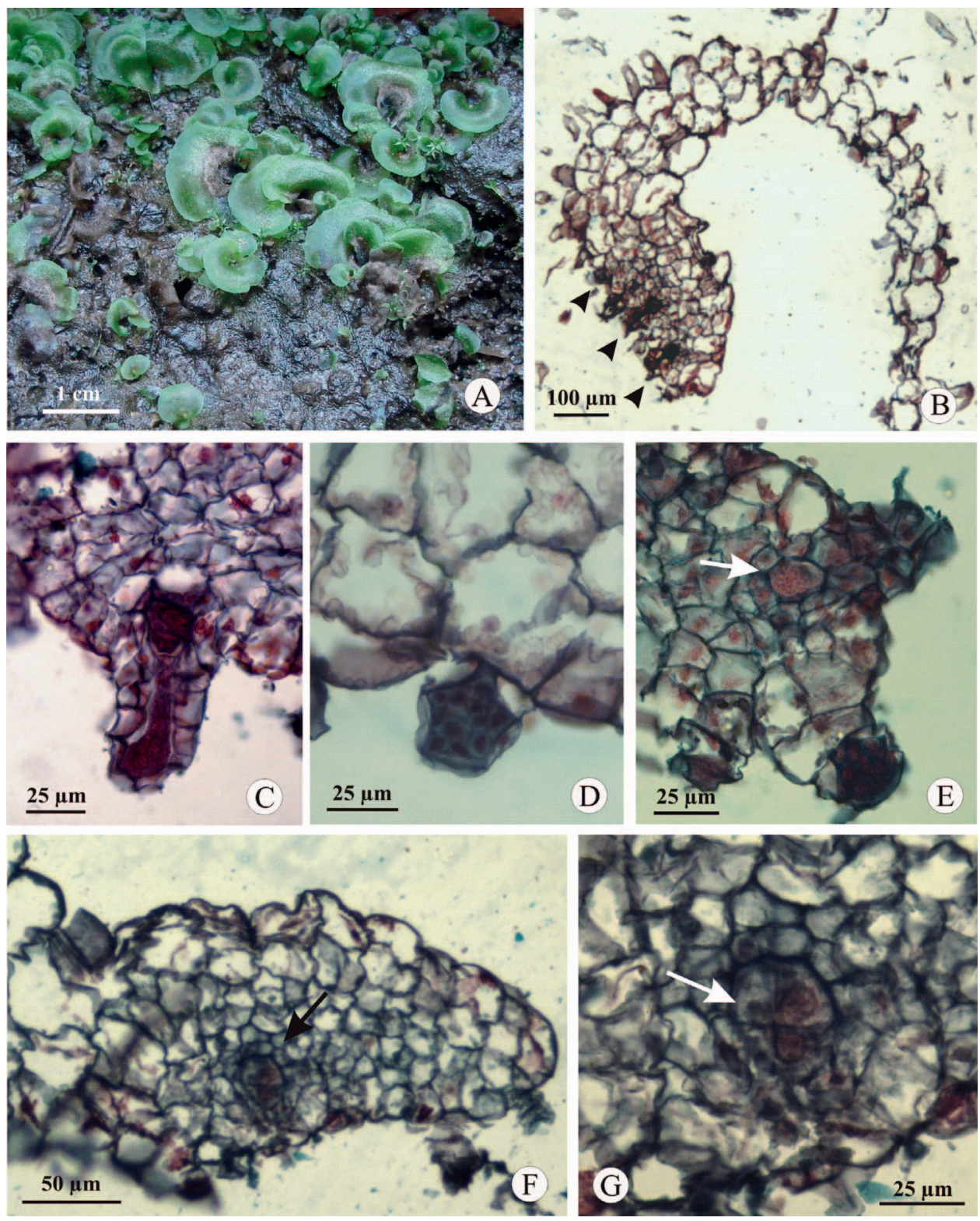

Fig. 1. Morphology of the green gametophyte. A: Macroscopic view of funnel-shaped prothalli. BG: Light micrographs. B: Section of a green gametophyte showing gametangia (arrowheads) in the multi-layered portion. C: Detail of an archegonium with the neck protruding from the gametophyte. D: An antheridium in detail. E: Fertilized archegonium with a zygote (arrow). F: Archegonium with a developing embryo (arrow). G: Detail of first mitotic divisions of the embryo (arrow). 

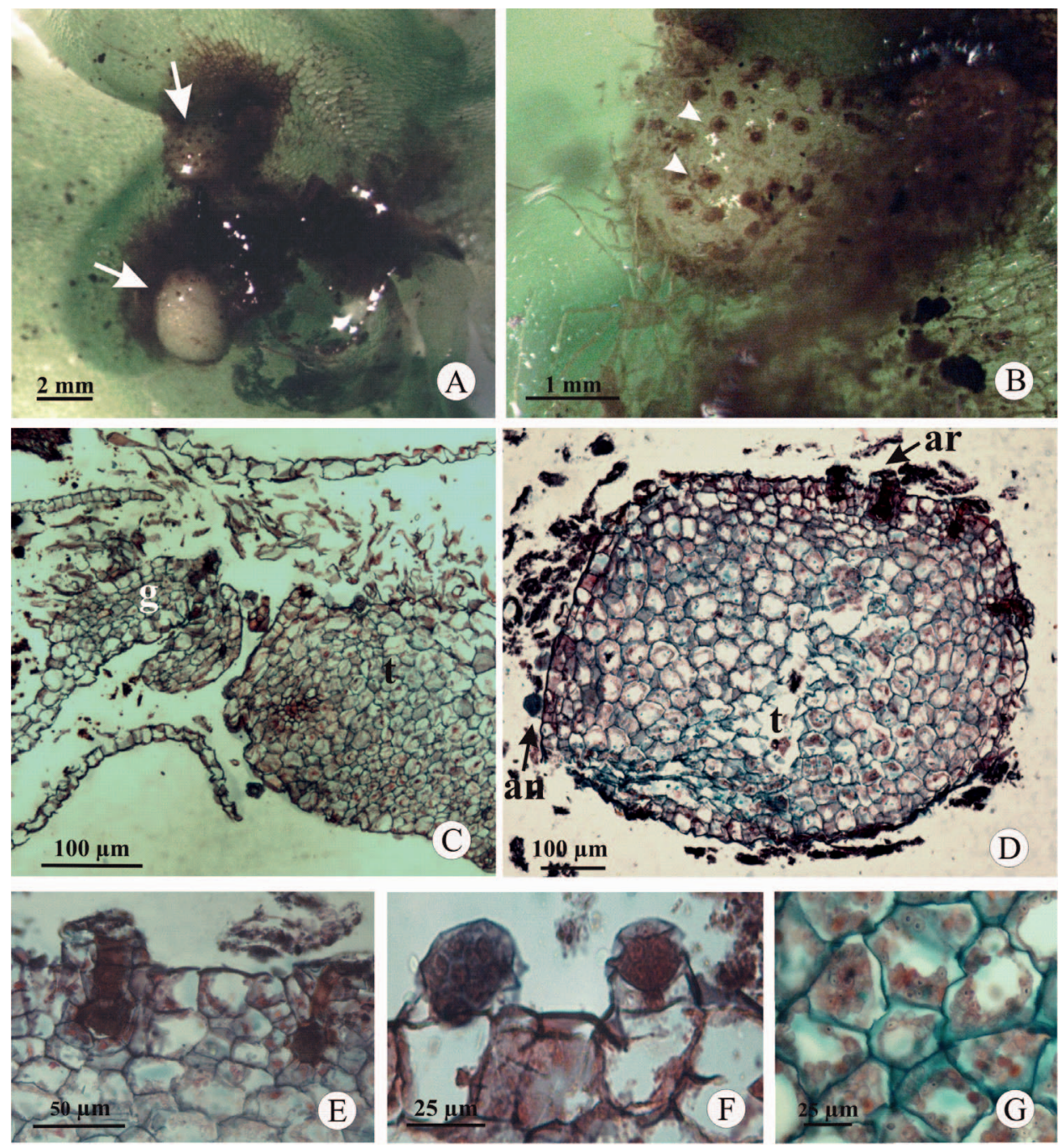

Fig. 2. Morphology of the tubercle. A-B: Macroscopic views. A: General aspect of tubercles covered (arrows) by rhizoids, developed on the green gametophyte' bottom surface. B: Detail of tubercle with numerous archegonia (arrowheads). C-G: Light micrographs. C: Section of a green gametophyte with a developed tubercle (right). Gametangia are observed in both zones. D: Detail of bisexual tubercle. E: Magnification of archegonia with their venters sunk in the tubercle. F: Magnification of antheridia showing basal, annular and opercular cells and antherozoids inside. G: Detail of deposits of starch grains in the tubercle. Abbreviations: antheridium (an), archegonium $(\mathrm{ar})$, green gametophyte $(\mathrm{g})$, tubercle $(\mathrm{t})$

sunk in the tubercle and their necks protrude 3-4 cells in length (Fig. 2 E). The antheridia show the typical basal, ring, and cap cells, and carry numerous antherozoids (Fig. 2F). The tubercle cells are thin walled and contain starch grains (Fig. 2G). As the tubercle matures, reserves accumulate inside its cells. 
Embryo and sporophyte.-After fertilization only one embryo was observed in each tubercle (Fig. 3A). At this point, oversized cells at the junction between the green gametophyte and the tubercle were observed (Fig. 3B). The embryo appears initially globose and then the shoot apex, the foot and the suspensor are differentiated (Figs. 3A, C). As the sporophyte grows, the tubercle opens forming a "calyptralike" outgrowth that allows the emergence of the shoot apex (Fig. 3D). Then the first developing leaves are observed (Fig. 3E). Nearly four months after spore sowing, the sporophyte consists of a short shoot with well-developed vascular tissues and a prominent foot (Fig. 4A). The foot includes cells with dense cytoplasm packed with abundant plastids. The placenta comprises the sporophyte foot cells and the adjacent gametophyte tubercle cells. Interdigitation between the cells of the two generations was noted (Fig. 4B). Intercellular spaces between sporophyte and gametophyte tissues were not observed. The shoot grows little in length and remains attached to the tubercle while the leaves develop (Fig 4C). Roots originate endogenously from the short shoot. During the development of the leaves the reserves of the tubercle are consumed (Fig. 4D). Vegetative propagation is also observed in the form of smaller tubercles that do not develop gametangia (Figs. 4D, E). During sporophyte growth, the first leaf developed early as a photosynthetic organ (Fig. 5A). The other leaves originate successively from the short shoot, while the green gametophyte and the tubercle remain functional in appearance (Fig. 5B).

\section{DisCUSSION}

The present study provides new information about the structure and development of the Anogramma chaerophylla gametophyte and sporophyte. During green gametophyte growth, we observed the development of antheridia and archegonia in the multilayered zone. Although Hagemann (1997) did not detect archegonia in the green gametophytes of $A$. chaerophylla, we agree with Baroutsis (1976) in that archegonia may be present outside the tubercle. Occasionally, we detected fertilization and embryo development in the archegonia of the green gametophyte; however, in these cases, the sporophyte generation did not survive beyond a few mitotic divisions.

The green gametophyte of Anogramma chaerophylla produced bisexual tubercles on its lower surface. Hagemann (1997) observed the development of only one type of gametangium per tubercle (unisexual tubercles), which suggests that development may depend on culture conditions. Because tubercles of $A$. chaerophylla can develop both antheridia and archegonia, the term "archegoniophore" (Bower, 1923) does not seem appropriate for these structures.

At the green gametophyte-tubercle junction we documented the presence of oversized cells connecting these structures. This kind of cell has not been reported in other ferns. For Anogramma leptophylla, Hagemann (1997) mentioned the existence of a prosenchymatic tissue in the contact zone between the gametophyte and tubercle, and suggested the role of these tissues in the transport of substances. Given their position and shape, the oversized 

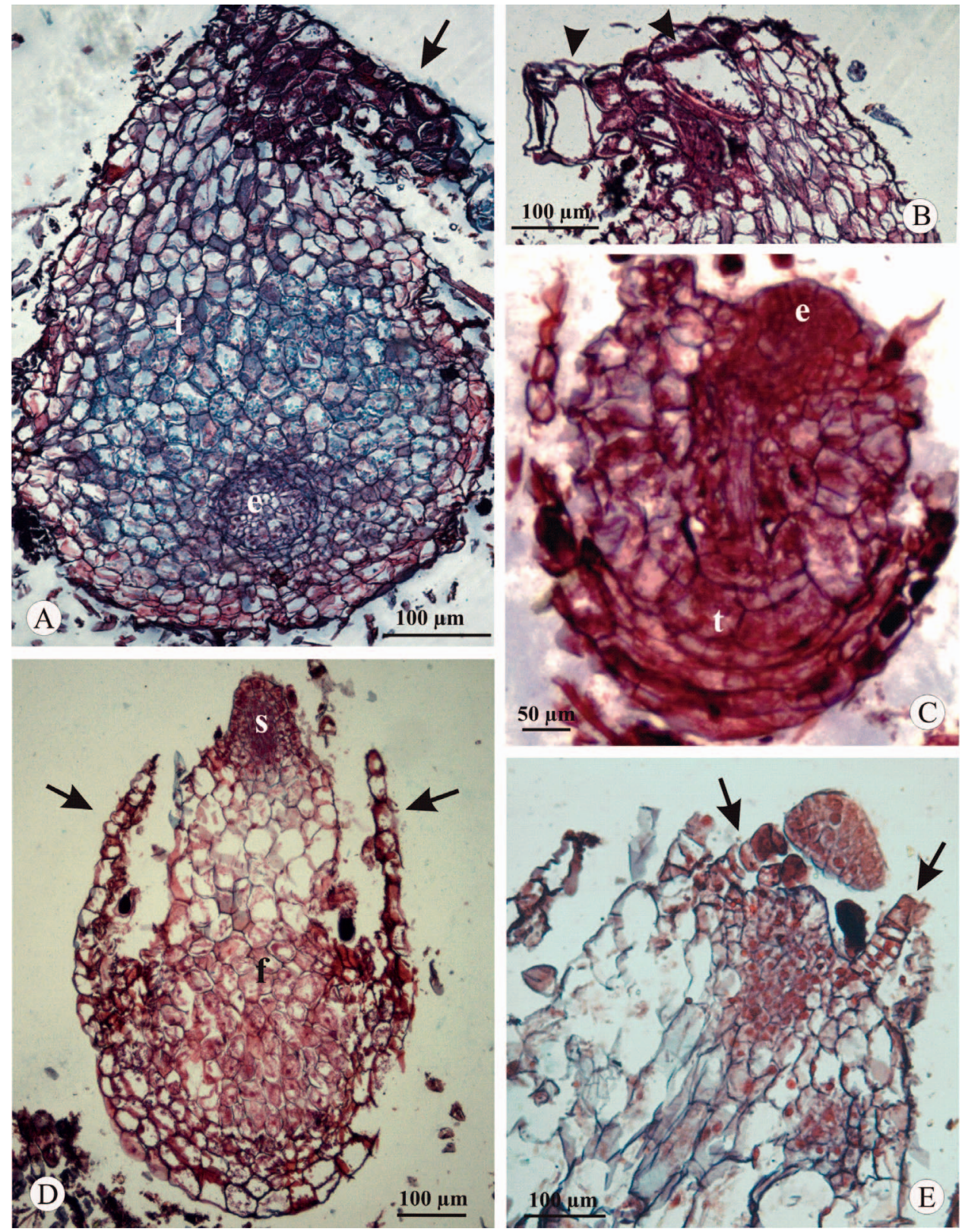

Fig. 3. Embryo development and sporophyte growth in tubercles. A: Section of a tubercle showing the occurrence of only one embryo. B: Detail of oversized cells (arrowheads) at the junction green gametophyte-tubercle. C: An embryo with differentiated shoot apex, suspensor and foot. D: Emergent sporophyte accompanied by calliptra-like outgrowths (arrows). E: Detail of shoot apex with the first developing leaves (arrows) and glandular hairs. Abbreviations: embryo (e), foot (f), sporophyte (s), tubercle (t) 

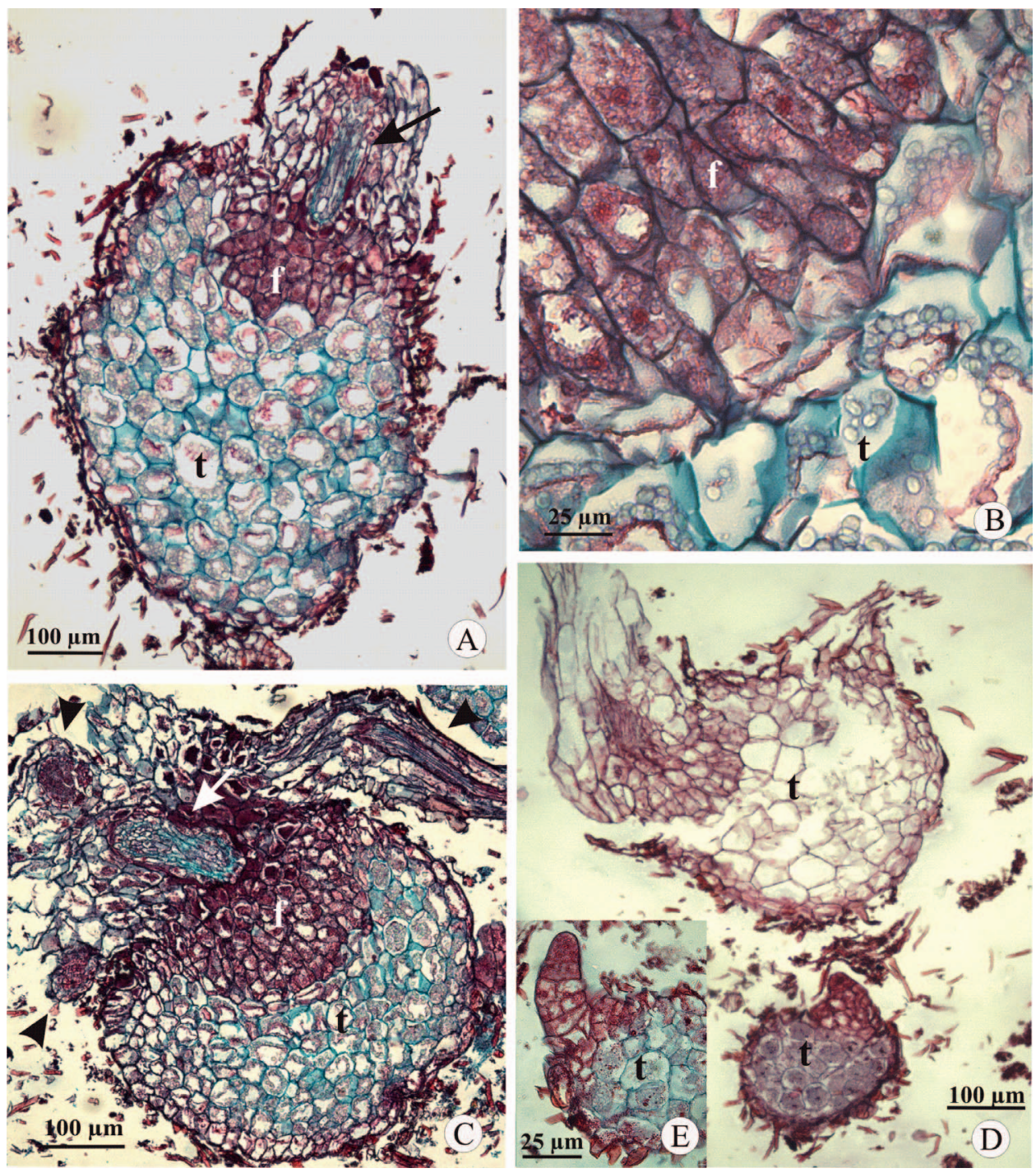

Fig. 4. Morphology of the young sporophyte. A: Tubercle with emerging sporophyte. Vascular tissues are already developed in the short rhizome (arrow). B: Detail of the contact zone (placenta) between the foot and tubercle cells. Note deposition of starch grains in both tissues. C: A more mature sporophyte (arrow) showing three developing leaves (arrowheads). The ones at left appear sectioned. D: Next step of sporophyte development along with complete consumption of the tubercle's food reserves. Note vegetative propagation in a small tubercle below. E: Detail of propagation in tubercle. Note the absence of gametangia. Abbreviations: foot (f), tubercle (t)

cells we observed could correspond to those cells described by Hagemann (1997). Further ultra-structural studies would help to ascertain if they are transfer cells and thus if they take part in the transport of substances between the green gametophyte and the tubercle. 

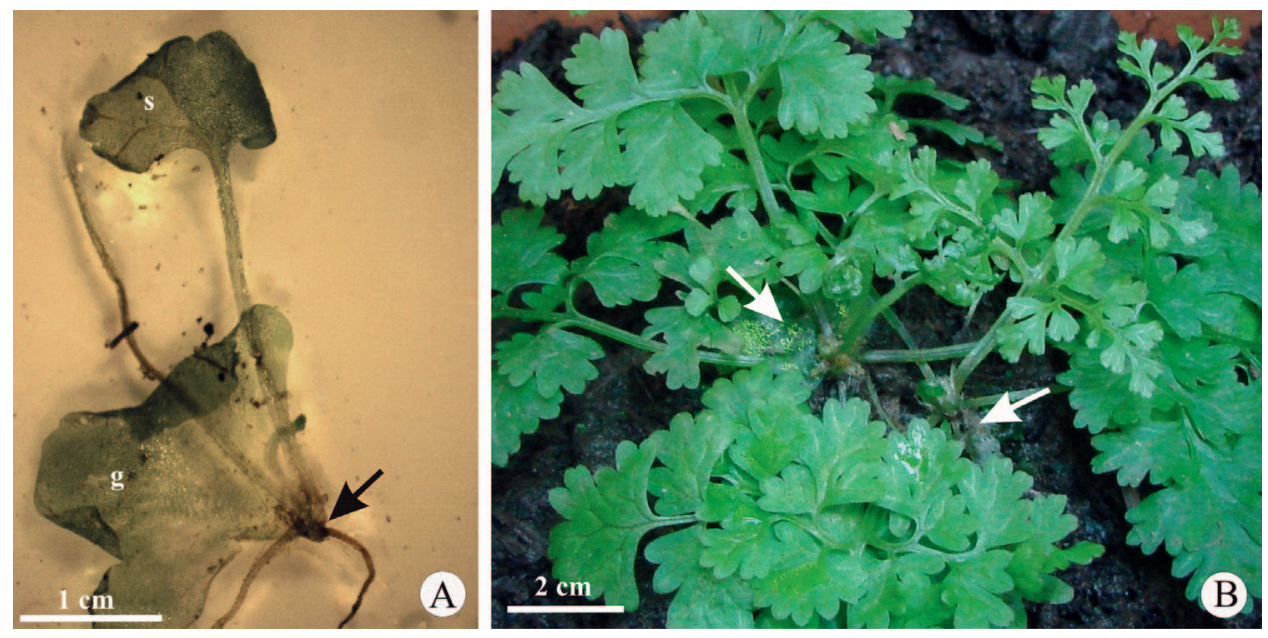

Fig. 5. Macroscopic views of sporophytes grown in laboratory. A: Sporophyte with first developing leaves emerging from the tubercle (arrow). Roots are also observed. B: More mature sporophytes with 4_5 developed leaves. The green prothalli are still visible (arrows). Abbreviations: green gametophyte (g); sporophyte (s)

Successful sporophytes developed exclusively in association with the tubercles, with only one sporophyte forming on each tubercle. Sporophyte growth was accompanied by the gradual consumption of the starch grains accumulated in the tubercle cells, in agreement with the findings of Pangua, Ruzafa, and Pajarón (2011) for Anogramma leptophylla.

Information on the structure and ultrastructure of the placenta is scarce in ferns. In species analyzed so far, the placentas comprise elongate haustorial sporophyte cells growing into the adjacent gametophyte cells (Duckett and Ligrone, 2003). In the case of Anogramma chaerophylla we observed interdigitation between the foot cells and the adjacent gametophyte cells. This coincides in general terms with observations on other leptosporangiate ferns such as Ceratopteris richardii Brongn., Gleichenia Sm. and Pteridium Gled. ex Scop. (Duckett and Ligrone, 2003; Johnson and Renzaglia, 2009). However, in the case of $A$. chaerophylla the gamethophytic tissue corresponds to the tubercle cells, whereas in the other ferns contact is established with the green gametophyte cells. Further ultra-structural studies in Anogramma would contribute to extending the knowledge on fern placentas.

The shoot of the young sporophyte protruded quickly from the tubercle and the first leaf developed early as a photosynthetic organ. Following Gifford and Foster (1989), this type of sporophyte growth enables early synthesis of its own nourishment. The rapid development of the Anogramma chaerophylla sporophyte would be related to its annual condition, allowing it to release the spores shortly before dying.

As another adaptive strategy, the foot cells came into contact with the tubercle storage cells and extended their haustorial function until the 
development of the fourth leaf. In ferns the foot serves as haustorial organ that attaches the embryo to the nutritive tissue of the gametophyte (Gifford and Foster, 1989). The presence of a fairly large foot is usual in embryos that depend nutritionally on the gametophyte for a relatively long time (Johnson and Renzaglia, 2009). Our findings in this species highlight the deep sporophyte-gametophyte nutritional dependency-via the tubercle in this case-when compared to other ferns. The fact that embryos originating in the green gametophyte portion, which lack the reserves of the tubercle, did not prosper supports this hypothesis.

We also documented vegetative propagation of Anogramma chaerophylla via smaller tubercules. It is known that tubercles can regenerate the green thalloid part of the gametophyte (Baroustis, 1976; Mehra and Sandhu, 1976; Hagemann, 1997). The main function of the tubercles, as proposed Goebel (1889), would be to keep populations in the gametophytic phase until conditions permitting sporophyte development occur. Our observations of very few sporophytes developed in the field would agree in principle with this hypothesis.

Future directions of study are to document environmental conditions in the study area (i.e., water availability, irradiance, temperature, and soil $\mathrm{pH}$ ), to gather valuable information concerning what natural populations require to survive. Also, as studies on development of sexuality in gametophytes are conducted mostly in cultural conditions (Ranker and Geiger, 2008), investigations in natural gametophyte populations would contribute to a better understanding the modes of reproduction in Anogramma.

\section{ACKNOWLEDGMENTS}

We thank the staff of Natural Reserve Punta Lara for their help during field trips. We are also grateful to the editors and two anonymous reviewers, whose valuable suggestions contributed to improve the quality of the manuscript. This study was supported by the Research Projects of Universidad Nacional de La Plata, Argentina (N/610 and N/725) and CONICET PIP 878.

\section{LiterATURE CiTED}

Baroutsis, J. G. 1976. Cytology, morphology, and developmental biology of the fern genus Anogramma. Ph. D. Thesis, Indiana University, Bloomington, Indiana.

Bower, F. O. 1923. The ferns. Vol 1. Cambridge University Press, London.

D’ambrogio De Argüeso, A. 1986. Manual de técnicas en histología vegetal. Editorial Hemisferio Sur, Buenos Aires.

Duckett, J. G. And R. Ligrone. 2003. The structure and development of haustorial placentas in leptosporangiate ferns provides a clearcut distinction between euphyllophytes and lycophytes. Annals of Botany 92: 513-552.

Gifford, E. M. And A.S. Foster. 1989. Morphology and evolution of vascular plants. W. H. Freeman, New York.

Goebel, K. 1889. Über die Jugendzustände der Pflanzen. Flora 72: 1-45.

Giudice, G.E., J. P. Ramos Giacosa, M. L. Luna, A. Yañez and E. R. De La Sota. 2011. Diversidad de helechos y licófitas de la Reserva Natural Punta Lara, Buenos Aires, Argentina. Revista de Biología Tropical 59: 1037-1046.

Hagemann, W. A. 1997. Über die Knöllchenbildung an den Gametophyten der Farngattung Anogramma. Stapfia 50: 375-391 
Johansen, D. A. 1940. Plant Microtechnique. McGraw-Hill, New York.

Johnson, G. P. And K.S. RenZaglia. 2009. Evaluating the diversity of pteridophyte embryology in the light of recent phylogenetic analyses leads to new inferences on character evolution. Plant Systematic and Evolution 283: 149-164.

Luna, M. L., A. Yañez, Ramos, J. P. Giacosa, D. Gorrer, P. C. Berrueta, and G. E. Giudice. In vitro spore culture and reproductive aspects of the anual fern Anogramma chaerophylla (Pteridaceae). Boletín de la Sociedad Argentina de Botánica. (In press).

Mehra P. N. And R. S. SAndhu. 1976. Morphology of the fern Anogramma leptophylla. Phytomorphology 26: 60-76.

Mickel, J. T. And A. R. Smith. 2004. The pteridophytes of Mexico. Memories of the New York Botanical Garden 88: 61-63.

Murashige, T. and F. Skoog. 1962. A revised medium for rapid growth and bio-assays with tobacco tissue culture. Physiologia Plantarum 15: 473-497.

Nakazato, T. and G. J. Gastony. 2003. Molecular phylogenetics of Anogramma species and related genera (Pteridaceae: Taenitidoideae). Systematic Botany 28: 490-502.

PAge, C. N. 2002. Ecological strategies in fern evolution: a neopteridological overview. Review of Palaeobotany and Palynology 119: 1-33.

Pangua, E. AND B. VEga. 1996. Comparative study of gametophyte development in Cosentinia and Anogramma (Hemionitidaceae) and Cheilanthes (Sinopteridaceae). Pp. 497-508, in: J. M. Camus, M. Gibby and R.J. Johns (eds.), Pteridology in Perspective. Royal Botanical Gardens Kew, London.

Pangua, E., I. P. Ruzafa and S. Pajarón 2011. Gametophyte features in a peculiar annual fern, Anogramma leptophylla. Annales Botanici Fennici 48: 465-472.

Ranker, T.A. And J.M. Geiger. 2008. Population genetics. Pp. 107-133, in: T. A. Ranker and C. H. Haufler (eds.), Biology and Evolution of Ferns and Lycophytes. Cambridge, Cambridge University Press.

Tryon, R., A. F. Tryon and K. U. Kramer. 1990. Pteridaceae. Pp. 230-256, in: K. U. Kramer and P. S. Green. (eds.), The families and genera of vascular plants. Vol. 1. Pteridophytes and gymnosperms. New York, Springer-Verlag.

Zuloaga, F. O., O. Morrone and M. J. Belgrano. 2008. Catálogo de las plantas vasculares del Cono Sur. Vol. 1. Pteridophyta, Gymnospermae y Monocotyledonae. Monographs in Systematic Botany from the Missouri Botanical Garden 107. 